\title{
Inhalt
}

\section{S. SCHMIDT}

Komponenten der Ertragsbildung bei Apfelbäumen. . . . . . . . . 461

H. KNUTH

Untersuchungen zur Arbeitsorganisation als Beitrag zur schrittweisen Verbesserung der Arbeits- und Lebensbedingungen der unter Glas und Plaste Tätigen, dargestellt am Beispiel der Gurkenproduktion (1. Mitteilung)

\section{J. REINHOLD}

Die Bedeutung der $\mathrm{CO}_{2}$-Messung bei der aeroben Mietenrotte fester tierischer Fäkalstoffe mit Zuschlagstoffen . . . . . . . . . . .

\section{P. Plietzsch}

Untersuchungen zur Ermittlung des Investitionsaufwandes großer moderner Gewächshauswirtschaften beim planmäßigen Übergang zu industriemäßigen Produktionsmethoden . . . . . . . . . .

H. Benkenstein und S. Wittig

Untersuchungen über den Einflu $\beta$ des Flüssigmulchens mit Bitumenemulsion auf Entwicklung und Ertrag von Tulpen (Tulipa) . . . . .

\section{Содержание}

\section{3. Шмидт}

Компоненты формирования урожая яблонь . . . . . . . . . . . . .

\section{Kнy'}

Исследования по организации труда как вклад в постепенное улучшение условий труда и жизни трудящихся, работающих в теплицах, на примере производства огурцов (I-ое сообщение) . . . . . . . . .

\section{Ё. РАЙНХольД}

Значение учета $\mathrm{CO}_{2}$ при аэробном компостировании уложенных в штабеля твердых фекальных веществ животных с добавками . . .

П. Плитцш

Исследования по определению затрат капиталовложений крупных современных тепличных хозяйств при планомерном переходе к методам промышленного производства . . . . . . . . . . . . . . .

Х. БЕНКЕНШТАЙН, З. ВИтТИГ

Изучение влияния жидкого мульчирования битумной эмульсией на развитие и урожайность тюльпанов (Tulipa). . . . . . . . . .

\section{Contents}

\section{S. SCHMIDT}

Factors of yield formation of apple trees .

H. KNUTH

Investigations into work organization as contribution to a gradual improvement of working and living conditions of people working in greenhouses under glass and plastic cover as shown by the example of cucumber production. (1st Communication) . . . . . . . . . . . . 469

\section{J. REINHOLD}

The importance of $\mathrm{CO}_{2}$ measuring in aerobic pit rotting of solid animal faeces with additives . . . . . 481

\section{P. Plietzsch}

Studies on the determination of investments for large modern greenhouse units during planful transition to industry-like production methods.

H. Benkenstein and S. Wittig

Studies on the effect of liquid mulching with bituminous emulsion on the development and yield of tulips (Tulipa) . . . . . . . . 499 